\title{
EFFECT OF AGITATED CHICKEN-DROPPINGS FOR IN SITU BIOREMEDIATION OF PAHS IN SPEND ENGINE-OIL CONTAMINATED SOIL
}

\author{
VE Okpashi*1, NE Etim², Inyang IH and UN Obeten ${ }^{4}$ \\ ${ }^{1}$ Department of Biochemistry, Cross River University of Technology, Calabar, Nigeria \\ ${ }^{2}$ Department of Environmental Education, University of Calabar, Nigeria \\ ${ }^{3}$ Department of Microbiology, Cross River University of Technology, Calabar, Nigeria \\ ${ }^{4}$ Department of Chemistry/Biochemistry and Molecular Biology, Alex-Ekwueme Federal University, Ndufu- \\ Alike, Abakiliki, Ebony State, Nigeria
}

\begin{abstract}
The populace are concern about how their environment is impacted by spend or used engine oil. The spills from spend engine oil posed serious problems to the land and aquatic habitats. Efficient methods but low-cost technique for remediating spends engine oil contaminated soil and restorations of soil fertility are being explored. In response to used engine oil pollution to the soil, the present investigation examined the comparative biodegradation level of spend engine oil contaminated soil using fermented chicken droppings. The soil sample was collected from the uncontaminated site $10 \mathrm{~cm}$ below ground level. The sandy/loam soil was sieved with $2.5 \mathrm{~mm}$ mesh. A $4 \mathrm{~kg}$ of the soil was weighed into each bucket and contaminated with spend engine oil, the soil was contaminated with $150 \mathrm{ml}$ of the spend engine oil at a ratio of 1:27. A $27 \mathrm{~kg}$ of chicken droppings was mixed with 27 liters of water in a ratio of 1 $\mathrm{kg}$ : $1 \mathrm{~L}$. The mixture was left for 7 days to ferment and increase the microbial load. The contaminated soil was irrigated using an experimental design that included uncontaminated soil that was irrigated using normal water (positive control), contaminated soil that was irrigated using normal water (negative control) and contaminated soil irrigated using fermented chicken droppings (test). Five hundred $\mathrm{mL}$ of the chicken droppings mixture was used to irrigate the soil for 21 days at an interval of 3 days per irrigation. Thereafter, the irrigated soil was screened with gas chromatography linked with mass spectroscopy. There was an observed change in contaminant concentration without fermented chicken droppings. The percentage of differences in the concentrations was recorded in $\times 10^{-5} \%$ with the presence of Naphthalene and Acenaphthylene with the percent difference of $2.0 \times 10^{-5} \%$ and $5.0 \times 10^{-}$ $5 \%$. Result revealed an appreciable decrease in PAHs level compared to the positive and negative control. The findings suggest the positive effect and rapid uptake of the contaminant in the application of fermented chicken droppings.
\end{abstract}

Key words: Bioremediation, Chicken droppings, Environmental pollution, Spend-engine oil

\section{Introduction}

In the ages, there has been a wide discharge of spend-oil on the soil without caring about the impact it may cause to soil ecology. Spend engine-oil is one of the petrochemical waste-products that is generated or spilled by auto mechanics repairers, this spend oil is always disposed and sometimes reuse for other purposes - lubricating and greasing automobile engines (Adu et al. 2015). Its distribution is attributed to the unguarded discharge of spend-oil from divers' sources. An investigation has revealed that the main source of

*Author for correspondence: vic2reshu@gmail.com 
oil contamination is through oil spills (Sagay et al. 2011). In recent times, spend oil that is spilled at automechanic workshops is left uncared for, while the spend-oil continuous to melt, leach and partition in the soil strata (Abdulsalam et al. 2012). Different methods to removing such contaminants have been adopted ranging from bioremediation (the use of microorganisms or immobilized and genetically engineered microorganisms) Nwankwegu et al. (2016). Some techniques for removing recalcitrant contaminants include bio-stimulation, bio-augmentation, bioventing, sparging, slurping, phytoremediation, composting, land farming and piles (Vidali 2001). The utilization of brewery mash and earthworm for remediation of petroleum hydrocarbons was adopted by (Okpashi et al. 2015). The ability of microorganisms to use-up petroleum hydrocarbon depends on certain factors, such as time or duration, concentration, composition, abiotic and biotic constituents of the contaminated soil (Lee et al. 2007). The application of microorganisms to break down polycyclic aromatic hydrocarbons (PAHs) in the soil has been recognized as an efficient, versatile, and environmentally responsive treatment technique (Yakubu 2007). One hopeful process is the application of chemical fertilizers to supplement the mineral elements such as nitrogen and phosphorus shortfall in the soil during biodegradation (Margesin and Schinner 1999). The search for the best consortium of microorganisms and nutrients for efficient bioremediation, and environmentally friendly are ongoing, and the best alternate options are needed to facilitate the rapid and efficient removal of petroleum contaminants. Another of such approaches was the utilization of agro (banana, pineapple, and Watermelon) wastes as consortiums to remediating cyanide contaminated soil (Florence et al. 2018), the in situ bioremediation of total petroleum hydrocarbons (TPHs) in spend-oil contaminated soil was subsequently remediated by irrigating the polluted soil with fermented chicken-droppings (Okpashi et al. 2020). An investigation on the subtypes of saprophytes and crude oil-degrading microbes from cow manure and fowl mulches submitted that the tallying of fowl manures to polluted soils are beneficial since it mends the proliferation of micro-flora that curbed the elongation of crude oil in the polluted soil (Godleads et al. 2015) In another report, the authors reported that organic enricher improves the bacteriological exploitation of petroleum hydrocarbons. The effect of an organic nutrient on biodegradation of lubricant polluted soil was assessed further with a proposition that the addition of organic nutrients improves the microbial application (Rose et al. 2012). The discharges of used engine oil on the soil ecosystem usually affect the properties of the soil. The transportation of leaked oil in the subsoil occurs in the manifold segment - (pores filled with water-oil or water-oil) and in a sole phase flow i.e. pores filled with water where hydrocarbons are liquefied (Isaac and Labunmi 2010). In this research, the capability of agitated chicken droppings to biodegrade the persistent polycyclic aromatic hydrocarbons (PAHs) compounds contaminated soil was appraised in-situ by reforming a scenario of the auto mechanic yard.

\section{Materials and Methods}

\section{Chemicals and reagents}

The chemicals and reagents used for this research were of analytical grade and purchased at JOECHEM Distribution Company limited at the Ogige market, Nsukka, Nigeria.

\section{Collection of soil sample}

The soil samples were a mixture of sandy-loam soil, collected from the farm of the Department of Soil Science, University of Nigeria, Nsukka. The soil sample location had not been exposed to petroleum hydrocarbon pollution. The soil was collected at a distance of $10 \mathrm{~cm}$ deep from the ground level and was airdried before sieving with $2.5 \mathrm{~mm}$ mesh. A four kilogram of the soil sample was balanced into 13 perforated 
buckets to permit ventilation and avert waterlog. The sand-filled buckets were placed in an environment with a regulated temperature.

\section{Collection of chicken droppings}

The chicken droppings were collected from a poultry farm at Ogige-Nsukka, Nigeria. A $27 \mathrm{~kg}$ of dried chicken droppings mixing with 27 liters of water in a ratio of one kilogram: one liter. The mixture was painstakingly stirred and placed in an air-tight vessel and kept in a temperature-regulated environment. This enables the dried chicken matter to dissolve and ferment to intensify the microbial mass of the mixture. The chicken droppings mixture was allowed for 7 days, after which it was diluted with water and used for irrigation of the PAHs contaminated soil.

\section{Collection of Spend engine oil}

The engine oil used in mixing/spiking the soil was collected from the auto-mechanic plot, of the Department of Mechanical Engineering, University of Nigeria, Nsukka.

\section{Contamination of the soil sample by Spend engine oil}

The soil was grouped in triplicates, $150 \mathrm{ml}$ of the used engine oil was mixed with four kilograms of the soil at ratio 1:27, and allowed to equilibrate for one week to ensure assimilation of the oil into the soil before the introduction of agitated chicken droppings.

\section{Irrigation of Spend engine oil contaminated soil with fermented chicken droppings}

A $500 \mathrm{ml}$ of the fermented chicken droppings mixture was introduced into the contaminated soil sample at a measured interval of three days per irrigation for 21 days. After the irrigation period of 21 days, normal water was used to irrigate the soil at a ratio of 1:8.

\section{Valuation Polycyclic Aromatic Hydrocarbons (PAHs)}

The method for estimating PAHs was adopted by (Okpashi et al. 2017). The oil composition of the contaminated soil sample before irrigation with chicken droppings and after irrigation was determined using Gas Chromatography tandem mass spectroscopy. Fifteen grams of each of the sample was weighed into 50 $\mathrm{ml}$ conical flasks, after which $1 \mathrm{ml}$ of $60 \mu \mathrm{g} / \mathrm{ml}$ of the chloro-octadecane surrogate standard was added. A 30 $\mathrm{ml}$ of the extraction solvent - dichloromethane was added to extract the oil in the soil. The concoction was agitated robustly in a water bath for five hours and allowed for one hour to stand. Thereafter, the mixture was filtered over Whatman No.1 filter paper. The residue was washed with $20 \mathrm{ml}$ of the extracting solvent and filtered through a funnel. The extracted oil was transferred to a vial and placed on a Gas Chromatograph for analysis. The amount of degraded oil was calculated by deducting the weight of residual oil from the weight of the initial oil, divided by the weight of initial oil and multiplied by 100, see Equation 1 below.

$\mathrm{TPH}$ for soil $(\mathrm{mg} / \mathrm{kg})=\frac{\text { herrum ant rading } x \text { total weighe of extract }}{\text { weight of sample }}$

\section{Condition of GC-MS (Gas Chromatography-Tandem Mass Spectroscopy) during the analysis}

The method was adopted by Okpashi et al. (2017). The following conditions apply to the use of Gas chromatographic-tandem mass spectroscopy techniques. GC/MS-QP2010 Agilent Plus, Ion source temperature: $200.00^{\circ} \mathrm{C}$, interface temperature: $250.00^{\circ} \mathrm{C}$, solvent cut time: 2.50 min, detector gain mode: MS, detector gain: $0.00 \mathrm{kV}$, threshold: 2000 , column oven initial temperature: $70.0^{\circ} \mathrm{C}$, injection final temperature: $250.00^{\circ} \mathrm{C}$, injection mode: split, flow control mode: linear velocity, pressure: $116.9 \mathrm{kPa}$, total flow: $40.8 \mathrm{ml} / \mathrm{min}$, column flow: $1.80 \mathrm{~m} / / \mathrm{min}$, linear velocity: $49.2 \mathrm{~cm} / \mathrm{sec}$, trap and purge flow: $3.0 \mathrm{ml} / \mathrm{min}$, split 
ratio: 20.0, high-pressure injection: off, carrier gas: helium, and splitter hold: off, respectively. The oven rating was as follows: oven temp. Program Rate Temperature $\left({ }^{\circ} \mathrm{C}\right)$ Hold Time (min) Initial: 0.0070 .00 .00 Final: 10.02805 .00 , consequently.

\section{Statistical analysis}

Investigations were carried out in triplicates and analyzed with Scientific Package for Science Student (SPSS) version 21. A one-way analysis of variance was used to compare the mean difference among samples. Significance was accepted at $p<0.05$. Data are presented in mean \pm standard deviation using descriptive statistics.

\section{Results}

The result in Table 1 indicates the concentration of polycyclic aromatic hydrocarbon level of spend oilcontaminated soil that was irrigated with normal water (negative control). The uncontaminated soil was irrigated with normal water (positive control), and spends engine oil contaminated soil that was irrigated with chicken-droppings. Their comparative examinations reveal that sixteen priority PAHs with concern to the environmental threat was detected. They ranged from Naphthalene to Indeno 1, 2, 3-cd) pyrene. The screening of the uncontaminated soil (positive control), indicates the presence of two PAHs Naphthalene and Acenaphthylene (Table 2). However, Naphthalene with a retention time of $5.123 \mathrm{~min}$ had $0.69 \mathrm{mg} / \mathrm{kg}$. Upon irrigation with normal water (negative control), its concentration reduced to $0.67 \mathrm{mg} / \mathrm{kg}$. The irrigation with chicken-droppings further reduced the contaminant to $0.58 \mathrm{mg} / \mathrm{kg}$. Similarly, Acenaphthylene with the retention time of $7.675 \mathrm{~min}$, had $0.27 \mathrm{mg} / \mathrm{kg}$ for positive control, $0.22 \mathrm{mg} / \mathrm{kg}$ for negative control and 0.19 $\mathrm{mg} / \mathrm{kg}$ after irrigation with chicken-droppings. The rest of the PAHs beginning from Acenaphthene to Indeno $1,2,3-c d)$ pyrene were undetected. The spiking of spend oil with the soil, caused the presence and concentration of other PAHs contaminants as illustrated in negative control and chicken-droppings irrigated column.

There are great variations in the reduction of PAHs contaminants between the positive control and chickendroppings irrigated soil. For example, fluoranthene with a retention time of $13.700 \mathrm{~min}$ had $1.12 \mathrm{mg} / \mathrm{kg}$ negative control and declined to $0.98 \mathrm{mg} / \mathrm{kg}$ after irrigation with chicken droppings.

Table 1. PAHs concentration in contaminated and uncontaminated soil after irrigation with water and chicken droppings

\begin{tabular}{lcccc}
\hline Compound & $\begin{array}{c}\text { Retention } \\
\text { time } \\
\text { (min) }\end{array}$ & $\begin{array}{c}\text { The concentration of } \\
\text { PAHs in spend engine } \\
\text { oil contaminated soil } \\
\text { irrigated with normal } \\
\text { water } \\
\text { (Negative Control } \\
\text { Mg/kg) }\end{array}$ & $\begin{array}{c}\text { The concentration of } \\
\text { PAHs in } \\
\text { uncontaminated soil } \\
\text { irrigated with normal } \\
\text { water } \\
\text { (Positive control } \\
\text { Mg/kg) }\end{array}$ & $\begin{array}{c}\text { The concentration of spend } \\
\text { engine oil contaminated soil } \\
\text { irrigated with Chicken- } \\
\text { droppings } \\
\text { Mg/kg }\end{array}$ \\
\hline Naphthalene & 5.123 & 0.67 & 0.69 & \\
Acenaphthylene & 7.675 & 0.22 & Not detected & 0.58 \\
Acenaphthene & 7.795 & 0.28 & Not detected & 0.19 \\
Fluorine & 8.876 & 0.42 & Not detected & 0.24 \\
Phenanthrene & 10.896 & 0.19 & Not detected & 0.37 \\
Anthracene & 11.171 & 0.67 & Not detected & 0.17 \\
Fluoranthene & 13.700 & 1.12 & Not detected & 0.59 \\
Pyrene & 14.369 & 0.36 & Not detected & 0.98 \\
Benz (a) anthracene & 16.984 & 1.21 & Not detected & 0.32 \\
Chrysene & 17.179 & 1.50 & & 1.06 \\
\hline
\end{tabular}


Contd. Table 1

\begin{tabular}{lllll}
\hline Benzo (b) fluoranthene & 19.536 & 3.81 & Not detected & 3.34 \\
000207-08-9 Benzo(k) & 19.845 & 3.51 & Not detected & 3.08 \\
000050-32-8 Benzo (a) & 20.303 & 2.19 & Not detected & 1.92 \\
Benzo (ghi) perylene & 21.402 & 5.05 & Not detected & 4.42 \\
Dibenzo (a,h) anthracene & 21.579 & 2.39 & Not detected & 2.09 \\
Indeno 1,2,3-cd) pyrene & 24.017 & 8.65 & Not detected & 7.57 \\
\hline
\end{tabular}

Similarly, Benzo (b) fluoranthene with retention time - $19.536 \mathrm{~min}$, had $3.81 \mathrm{mg} / \mathrm{kg}$ in the negative control but reduced to $3.34 \mathrm{mg} / \mathrm{kg}$ after irrigated with chicken-droppings. The obtained findings represent the effectiveness and efficiency of chicken droppings in mobilizing microorganisms that with the capacity to produce bio-emulsifier increase the affinity and activities of soil enzymes for the uptake of the soil contaminants.

Table 2. Comparative analyses of PAHs detected in contaminated and uncontaminated soil

\begin{tabular}{lllll}
\hline Compounds & $\begin{array}{l}\text { Concentration } \\
(\mathrm{mg} / \mathrm{kg})\end{array}$ & $\begin{array}{l}\text { Concentration } \\
(\mathrm{mg} / \mathrm{kg})\end{array}$ & $\begin{array}{l}\text { Concentration } \\
\text { difference } \\
(\mathrm{mg} / \mathrm{kg})\end{array}$ & $\begin{array}{l}\text { \% difference } \\
\left(\times 10^{-6 \%}\right)\end{array}$ \\
\hline Negative Control & Positive Control & 0.69 & 0.02 & 2.0 \\
Naphthalene & 0.67 & 0.69 & 0.05 & 5.0 \\
\hline
\end{tabular}

Negative control indicates contaminated soil irrigated with normal water, positive control means uncontaminated soil irrigated with normal water. Concentration difference is the change between the positive control and negative control. The percentage difference is the arithmetic difference in concentration.

There was an observed change in contaminant concentration without fermented chicken droppings. Though it was slow, natural degradation usually occurs in the absence of degrading organisms as seen in Table 2. The percentage difference in the concentrations is presented in $\times 10^{-5} \%$ with the presence of naphthalene and acenaphthylene with percent difference of $2.0 \times 10^{-5} \%$ and $5.0 \times 10^{-5} \%$.

Table 3. Concentration difference and percent difference between negative control and contaminated soil irrigated with chicken droppings

\begin{tabular}{lcccc}
\hline Compounds & $\begin{array}{c}\text { Concentration } \\
(\mathrm{mg} / \mathrm{kg}) \\
\text { Negative Control }\end{array}$ & $\begin{array}{c}\text { Concentration } \\
(\mathrm{mg} / \mathrm{kg}) \\
\text { Chicken } \\
\text { droppings }\end{array}$ & $\begin{array}{c}\text { Concentration } \\
\text { difference } \\
(\mathrm{mg} / \mathrm{kg})\end{array}$ & $\begin{array}{c}\% \text { difference } \\
\left(\times 10^{-60}\right)\end{array}$ \\
\hline Naphthalene & 0.67 & 0.58 & 0.09 & 9.0 \\
Acenaphthylene & 0.22 & 0.19 & 0.03 & 3.0 \\
Acenaphthene & 0.28 & 0.24 & 0.04 & 4.0 \\
Fluorine & 0.42 & 0.37 & 0.05 & 5.0 \\
\hline
\end{tabular}


Contd. Table 3

\begin{tabular}{lllll}
\hline Phenanthrene & 0.19 & 0.17 & 0.02 & 2.0 \\
Anthracene & 0.67 & 0.59 & 0.08 & 8.0 \\
Fluoranthene & 1.12 & 0.98 & 0.14 & 1.4 \\
Pyrene & 0.36 & 0.32 & 0.04 & 4.0 \\
Benz (a) anthracene & 1.21 & 1.06 & 0.15 & 1.5 \\
Chrysene & 1.50 & 1.32 & 0.18 & 1.8 \\
Benzo (b) fluoranthene & 3.81 & 3.34 & 0.47 & 4.7 \\
000207-08-9 Benzo(k) & 3.51 & 3.08 & 0.43 & 4.3 \\
000050-32-8 Benzo (a) & 2.19 & 1.92 & 0.27 & 2.7 \\
Benzo (ghi) perylene & 5.05 & 4.42 & 0.63 & 6.3 \\
Dibenzo (a,h) anthracene & 2.39 & 2.09 & 0.30 & 3.0 \\
Indeno 1,2,3-cd) pyrene & 8.65 & 7.57 & 1.08 & 10.8 \\
\hline
\end{tabular}

The percentage difference was calculated by subtracting the values of the group irrigated with fermented chicken droppings form of the negative control (group irrigated with normal water) from the negative control (group irrigated with normal water). This negative control takes care of the perception that under normal environmental pollution, there must be raining reasons which may cause the rapid degradation of polluted land. However, the irrigation with fermented chicken droppings facilitated the rapid degradation of residual recalcitrant pollutants. That is why percentage degradation was calculated to establish the level of contaminant's reduction and soil recovery after twenty-one days. For instance, Naphthalene gave a 9\% reduction after irrigation with chicken droppings in Table 3, while with normal water (negative control), the reduction level was $2 \%$. Also, Benzo (ghi) perylene had $5.05 \mathrm{mg} / \mathrm{kg}$ negative control but reduced to 4.42 $\mathrm{mg} / \mathrm{kg}$. Their difference gave $0.63 \mathrm{mg} / \mathrm{kg}$ equivalent to $6.3 \%$. The percentage difference in the concentrations is presented in $\times 10^{-5} \%$ with Indeno-1, 2, 3-cd) pyrene showing the highest degradation of $10.8 \times 10^{-5 \%}$ difference and phenanthrene showing the lowest degradation of $2.0 \times 10-5 \%$ difference.

\section{Discussion}

The expansion and activities of the auto-mechanic shops in Nigeria and the distribution of spend petroleum products have led to pollution of terrestrial environments (Onuorah et al. 2018). The effects of this pollution have been shown in decreased agricultural productivity of soil, health hazards, and increased deterioration of health and natural resources. These responses are being made concerning the degradation of spend petroleum hydrocarbon resulting from spilled oil (Margesin and Schinner 2001). This has led to investigations using organic wastes as amendment materials for soil bioremediation and possible restoration of soil fertility. The availability of high PAHs in the soil affects the proliferation of native microorganisms which caused relaxed degradation of the hydrocarbons contaminants in the soil (Gavrilescu 2010).

Table 1 indicates the polycyclic aromatic hydrocarbon level of spend oil-contaminated soil that was irrigated with water (negative control). The uncontaminated soil that was irrigated with water (positive control), and 
spends oil-contaminated soil that was irrigated with chicken-droppings (test group). A relative investigation reveals that sixteen priority PAHs with concern to the environmental threat was detected. They stretched from Naphthalene to Indeno 1, 2, 3-cd) pyrene. The screening of the uncontaminated soil (positive control), specifies the presence of two PAHs Naphthalene and Acenaphthylene, also in Table 2. Naphthalene had 5.123 min retention time with $0.69 \mathrm{mg} / \mathrm{kg}$ for positive control. After irrigation with normal water (negative control), its concentration reduced to $0.67 \mathrm{mg} / \mathrm{kg}$. The irrigation with chicken-droppings further reduced the contaminant to $0.58 \mathrm{mg} / \mathrm{kg}$. Acenaphthylene had 7.675 min retention time with $0.27 \mathrm{mg} / \mathrm{kg}$ for positive control, $0.22 \mathrm{mg} / \mathrm{kg}$ for negative control and $0.19 \mathrm{mg} / \mathrm{kg}$ after irrigation with chicken-droppings. The rest of the PAHs starting from Acenaphthene to Indeno 1, 2, 3-cd) pyrene were undetected in the positive control group. The spiking of spend oil with the soil caused the presence and concentration of other PAHs contaminants seen in negative control and chicken-droppings irrigated soil (test group).

The amendment of the soils with varying echelons of organic wastes significantly reduces the hydrocarbons content of the soil by increasing the degradation hydrocarbons. However, the present investigation was carried out with fermented chicken droppings as the remediation material and it was applied to the contaminated soil. The results of the experiment revealed that the contaminated soil that had been treated with fermented chicken droppings showed a high rate of degradation by stimulation of microbial activity which led to the production of biosurfactants through enzymatic reactions. Photooxidation and regulated temperature of $30-40^{\circ} \mathrm{C}$ also affect the rate of biodegradation of the contaminant by increasing its bioavailability, affinity to the contaminants and enhancing microbial activities.

The results for the test obtained for Polycyclic Aromatic Hydrocarbon content revealed a considerable degree of biodegradation compared to the hydrocarbon content of the negative control (Okpashi et al. 2020). This could be attributed to the availability and proliferation of hydrocarbon-degrading microorganisms found in the chicken droppings concoction. The availability of nutrients in the ecosystem via irrigation with chicken droppings concoction led to the stimulation of the hydrocarbon-degrading microorganisms to proliferate, thereby increasing their microbial mass which might have surpassed the threshold concentration required for hydrocarbon degradation. At this concentration, biodegradation occurs by the production of biosurfactants by the microorganisms (Abdulyekeen et al. 2016).

The calculated percentage difference was done by subtracting the values in the group irrigated with fermented chicken droppings (test group) from negative control (group irrigated with water). The negative control takes care of the view that under normal environmental pollution, there must be raining reasons which will cause the pollutant to degrade with time. However, the irrigation with fermented chicken droppings effectively quickens the degradation of residual recalcitrant pollutants. That is why percentage degradation was calculated to establish the reduction level of contaminants and soil recovery after twenty-one days trial. For instance, Naphthalene gave 9\% reduction after irrigation with chicken droppings in Table 3, while with normal water (negative control), the reduction level was $2 \%$ presented in Table 2. Also, Benzo (ghi) perylene had $5.05 \mathrm{mg} / \mathrm{kg}$ negative control but reduced to $4.42 \mathrm{mg} / \mathrm{kg}$. Their difference gave $0.63 \mathrm{mg} / \mathrm{kg}$ equivalent to $6.3 \%$. The percentage difference in the concentrations is presented in $\times 10-5 \%$ with Indeno-1, 2, 3-cd) pyrene presenting the highest degradation of $10.8 \times 10-5 \%$ difference and phenanthrene showing the lowest degradation of $2.0 \times 10^{-5} \%$ difference.

The biosurfactants produced emulsify the oil thus decreasing the hydrophobicity of the oil and solubilizing it (Ayotamuno et al. 2006). The biosurfactants increase the bioavailability of the oil thus increasing the capacity of the microorganisms to utilize the carbon chain of the compounds as a carbon source (Abioye et al, 2012). The biodegradation capacity of the chicken droppings is shown in a concentration difference of Indeno-1,2,3- 
cd) pyrene with the highest degradation - $10.8 \times 10^{-5 \%}$ difference $(1.08 \mathrm{mg} / \mathrm{kg}$ concentration difference) for PAHS.

Previous bioremediation techniques that support microbial biodegradation have been carried out (Obire et al. 2008). The report from this work showed that the addition of cow dung or poultry droppings to polluted soils is beneficial since it enhances the proliferation of microflora that may be suppressed by the addition of crude oil to the soil. The effect of organic nutrient (poultry droppings) on biodegradation of crude oil polluted soil was further assessed with a suggestion that the addition of organic nutrients enhances microbial utilization of crude oil (Hwang et al. 2001). The bioremediation of hydrocarbon-contaminated soil using the composting process revealed that mixing of remediated soil with contaminated soil increased the effectiveness of composting. This is because the recycled soils usually have acclimated microorganisms that can significantly affect the degradation rate of contaminants (Agbor et al. 2018).

Microbial degradation of hydrocarbons is the major and ultimate natural mechanism by which cleanup of a hydrocarbon polluted environment can occur. The availability of nutrients affects the rate of biodegradation by influencing the enzymatic activities of the microorganisms. Although, it has been reported that excessive nutrients can inhibit biodegradation activity especially for aromatics hydrocarbons. However, chicken droppings have proved to be a potential bioremediation material for both bio-stimulation and bioaugmentation. This is due to their high microbial load of hydrocarbon-degrading microorganisms and nutrient capacity required for the proliferation of these organisms.

\section{Conclusion}

This study showed that agitated chicken droppings supported the remediation of PAHs polluted soil. Agitated chicken droppings are a potential source of nutrients for microbial activity and it harbored microorganisms are capable of utilizing hydrocarbons as a source of carbon and energy source. Thus, potentially useful in soil hydrocarbon pollution response action.

Conflict of interest: The authors hereby declare no competing interest exist regarding the publication of this article.

Contribution: Authors contributed equally in the research.

\section{References}

Abdulsalam S, Adefia SS, Bugaje IM and Ibrahim S (2012). Bioremediation of soil contaminated with used motor oil in a closed system. J. Bioremediation and Biodegradation, 3(12): 39.

Abdulyekeen KA, Muhammad IM, Giwa SO and Abdulsalam S (2016). Bioremediation of used motor oil contaminated soil using elephant and horse dung as stimulants. J. Environ. Science, Toxicology and Food Tech., 10(12): 73-78.

Abioye OP, Agamuthu P and Abdul AA (2012).Biodegradation of Used Motor Oil in Soil Using Organic Waste Amendments. Biotechnology Research International, 215: 25-29.

Adu AA, Aderinola OJ and Kusemiju V (2015).Comparative effects of spent engine oil and unused engine oil on the growth and yield of Vignaunguiculata (Cowpea). Inter J. Science and Technology, 4(3): 105-118.

Agbor RB, Antai SP and Nkanang AJ (2018). Microbial degradation of total petroleum hydrocarbon in crude oil polluted soil ameliorated with agro-wastes. Global Journal of Earth and Environmental Science, 3: 1-7.

Ayotamuno MJ, Kogbara RB, Ogaji SOT and Probert SD (2006). Bioremediation of crude oil polluted agricultural soil at Port Harcourt, Nigeria. Applied Energy, 83: 1249-1257. 
Florence ON, Samuel CU, Okpashi VE, Nwankwo NE, Sandra AG, Blessing CN and OFC Nwodo (2018). Utilization of Banana, Pineapple and Watermelon Wastes- Substrate: As Consortiums to Remediating Cyanide Polluted Soil. Am. J. Env. Sciences, 14(4): 77- 85.

Gavrilescu M (2010). Environmental Biotechnology: Achievements, opportunities, and challenges. Dynamic Biochemistry, Process Biotec, and Molecular Biology, 4(1): 1-36.

Godleads OA, Prekeyi TF and Samson EO (2015). Ehinomen I. Bioremediation, Biostimulation, and Bioaugmentation: A Review. International Journal of Environmental Bioremediation and Biodegradation, 3(1): 28-39.

Hwang E, Namkoog W and Park J (2001). Recycling of remediated soil for effective composting of diesel-contaminated soil. Compost Science and Utilization, 4 (3): 143-149.

Isaac AO and Labunmi L (2010). Exposure level and bioaccumulation of polycyclic aromatic hydrocarbons (PAHs) in edible marine organisms. J. Environ. Indicators, 5: 69-88.

Lee SH, Lee S, Kim DY and Kim JG (2007). Degradation characteristics of waste lubricants under different nutrient conditions. Journal of Hazardous Materials, 143(1): 65-72.

Margesin R and Schinner F (1999). A feasibility study for the in situ remediations of a former tank farm. World Journal of Microbiology and Biotechnology, 15: 615-622.

Margesin R and Schinner F (2001). Bioremediation (natural attenuation and biostimulation) of diesel oil-contaminated soil in an Alpine Glacier skiing area. Applied Environ. Microbio, 67: 3127-3133.

Nwankwegu AS, Onwosi CO, Orji MU, Anaukwu CG, Okafor UC, Azi F and Marins PE (2016). Reclamation of DPK hydrocarbon polluted agricultural soil using a selected bulking agent. J. Environmental Management 172: 136-142.

Obire O, Anyanwu EC and Okigbo RN (2008).Saprophytic and crude oil-degrading fungi from cow dung and poultry droppings as bioremediation agents. J. Agricultural Techn, 4(2): 81-89.

Okpashi VE, Ogugua VN, Joshua PE, Ubani CS, Oje OA, Akpo DM, Uroko RI and Onwurah INE (2017). Comparability assessment of polycyclic aromatic hydrocarbons tissue load in some fish: implication on reciprocal synergism and risk assessment. American J. Environmental Sciences. DOI: 10.3844/ajessp

Okpashi VE, Igori W and Akpo DM (2015). Crude oil pollution and bio-remediation using brewery mash and earthworm (Nsukkadrilus mbae.) a consortium to cleaning-up and restoring the soil fertility potential. J. Petroleum and Environmental Biotechnology, 6: 223.doi:10.4172/2157-7463.1000223.

Okpashi VE, Ushie OA, Abeng FE and Inyang IH (2020). Monitoring the in situ bioremediation of spend engine-oil contaminated soil after irrigation with fermented chicken-droppings. Journal of Applied Science and Env. Manage, 24(3): 411-416.

Onuorah S, Soludo C and Odibo F (2018). Impact of pig manure on the chemical characteristics and microbial population of crude oil-polluted soil in Awka, Nigeria. American Journal of Life Science Researches, 6(1): 47-59.

Rose A, Ken D, Kehinde $O$ and Babajide A (2012). Bioaccumulation of polycyclic aromatic hydrocarbons in fish and invertebrates of Lagos lagoon, Nigeria. J. Emerg. Trends Eng. Applied Sci., 3: 287-296.

Sagay J, Edo ZO and Avweromre L (2011). Environmental degradation and the dilemma of sustainable development: implication for environmental security in the Niger. J. Env. Sciences and Resource Management, 3: 14-29.

Vidali M (2001). Bioremediation: An overview. Pure and Applied Chemistry, 73 (7): 1163-1172.

Yakubu MB (2007). Biodegradation of Lagoma crude oil using pig dung. African Journal of Biotechnology, 6: 2821-282. 